\section{Local Wisdom as the Media to Prevent the Activity of Violence toward Women in Minangkabau Society}

\author{
Ike Revita ${ }^{1, *}$, Fahmi Gunawan ${ }^{2}$, Rovika Trioclarise ${ }^{3}$, Nila \\ Anggreiny ${ }^{4}$ \\ 1 Universitas Andalas, Indonesia \\ 2 STAIN Kendari, Indonesia \\ 3 Poltekkes Kemenkes RI \\ 4 Universitas Andalas, Indonesia \\ *e-mail: ikerevita30@gmail.com
}

\begin{abstract}
Minangkabau is identical with the system of matrilineal in which the kinship is from the maternal line. This matrilineal system brings about the welfare of women in Minangkabau due to heirloom property is handed down to the female children. Thus, women will not be a lack of material. This phenomenon is contradictory with the activity of violence toward women in Minangkabau. Many Minangkabau women become the victim of violence, even though these women have adequate material inherited from their mother. This writing then tries to describe the local wisdom that can be revitalized to reduce the activity of violence toward women in Minangkabau society. The aim of the research is to identify the local wisdom in Minangkabau that can prevent violence toward women. The research is conducted in three areas in West Sumatera, they are Padang, Payakumbuh, and Tanah Datar. The data are collected by having an interview, focus group discussion, and observation. The analysis is done by relating it to the concept of local wisdom in Minangkabau and Violence toward women proposed by Idriss and Abbs and also Revita, Wekke, and Trioclarise. The result of the analysis is descriptively presented. Having analyzed the data, there is at least three local wisdom. They are 1) Adat Basandi Syarak, Syarak Basandi Kitabullah, 2) Bundo Kanduang), and 3) Alam Takambang Jadi Guru.
\end{abstract}

\section{Keywords}

Local wisdom, Minangkabau, Violence toward women

\section{Introduction}

Citation: Revita, I., Gunawan, F., Trioclarise, R \& Anggreiny, N.: Local Wisdom as the Media to Prevent the Activity of Violence toward Women in Minangkabau Society. In. D. Ekawati, et al (eds.): Proceeding of The American Studies International Conference 2018, Vol. 2. pp. 53-58 UGM Digital Press Social Sciences and Humanities, Yogyakarta (2019).

Published: May, 2019
Article 1 of the UN Declaration defines violence toward women as a kind of activity in which there is an act of gender-based violence that results in, or is likely to result in, physical, sexual or psychological harm or suffering to women, including threats of such acts, coercion or arbitrary deprivation of liberty, whether occurring in public or in private life.

This article, then, is followed by article 2 which states that violence against women must be understood to include, but not limited to: physical, sexual and psychological violence that occurs in the family and 
in the community including beatings, abuse sexual abuse of women and children, violence related to women, marital rape, marital rape, female genital mutilation and other traditional practices of violence against women, violence outside of husband and wife relations and violence related to women's exploitation, rape, sexual abuse, sexual harassment and threats at work, in educational institutions and so on, trafficking in women and forced prostitution and including violence committed and justified by any the state. (DEVAW, 1993)

These two definitions indicate that violence is basically all forms of behavior, both verbal and nonverbal, carried out by a person or group of people, against someone or a group of other people, causing a negative physical, emotional and psychological to the people who are the target (victims of violence) (Hayati, 2002) (Martha, 2003). The violence toward women created the misery of the women in which they do not deserve to get. The women are a creature that is supposed to be compassionate, to be loved, and to be protected. They are not for being hurt nor suffered. In fact, what the women should be gained occurs contradictory. They become victims of violence. This is what is found in Minangkabau.

As an ethnic in Indonesia with its very unique system of kinship in which mother becomes the line of lineage, Minangkabau traditionally keeps women in an honorable position. (Hastuti et al., 2013, pp.8-9) (Navies, 2017). Women in Minangkabau play a very important role not only in their family but also in society. (Revita, Trioclarise, Gunawan, 2017, p. 97-99). The women are called as Limpapeh Rumah Gadang. Rumah Gadang is Minangkabau traditional house in which Limpapeh is the hall of the house. This implies that women are very valuable. Even, these women are inherited with treasures like farm and rice field. This means Minangkabau women are equipped with the material to carry out their life. Materially, Minangkabau women are rich. They have no worry about their future. Economically, these Minangkabau women are also not supposed to be totally depending on their husband. However, this fact is contradictory with violence toward them. Still, many Minangkabau women become the victims in terms of physic, psychology, sexual, and economic as well.

This article becomes one way offered to overcome the problem related to the process of reviving and intensifying the role of the local wisdom in Minangkabau. There are many local pearls of wisdom found in Minangkabau society. This writing is aimed at describing the Minangkabau local wisdom that can prevent and protect women to be violated. The objectives are to identify the Minangkabau local wisdom that is possible to save women from the violence.

\section{Theoretical Framework}

Violence against women has been around since human civilization in each phase of life. Women become the creature who has the great potentiality to be the victims. A lot of violence toward women but were not identified. These are due to some factors like a) violence against women is considered a problem which does not need to be disclosed because it is not settled as these women as the victims are often blamed; 2) women as the victims of violence do not get maximal assistance yet from the police or government; 3) the violence toward women is not comprehensively socialized yet to the government as the policymakers, so there are no effective rules locally create. (Errikson, et al., 2013) Even, generally, women consider that violence is just about physical things like torture (slapped, grabbed, kicked, beaten, spat on).

This can bring about the rapid growth of violence toward women. The women themselves might not realize that they are the victims because certain culture and tradition lead women to just patiently accept what they have and face in their life as the wife. Even, they get harsh treatment from the ones they know better. (Oram et al., 2013)

The violence toward women is something related to suffering. Women as the victims of violence are not suffering physically but also psychologically. (Asmarany, 2007) This is in line with the concept of violence toward women as any action that results in misery or suffering-suffering to women physically, sexually or psychologically, including threats of certain actions, coercion or deprivation of freedom arbitrarily whether that occurs in public or in the environment of personal life. (Article 1 of the UN Declaration) (UU Nomor 23, 2004) The violence is divided into four. They are:

1. Physical violence: an action that aims to injure, torture or persecute others, by using the perpetrators' limbs (hands, feet) or with other tools. For example slapping, beating, crushing, rough pushing, kicking, strangulation, throwing hard objects, torture using sharp objects, such as knives, scissors, iron that burns. These actions may result in pain, illness, and seriously injured even to the death;

2. Psychological violence: an action to lower a woman's image, both through words and deeds (painful words, dirty words, shouting, humiliation, threats) that suppress women's emotions. These actions result 
in fear, loss of confidence, loss of ability to act, feelings of helplessness and/or severe psychological harm to someone;

3. Sexual violence: including sexual harassment, as well as various forms of coercion of sexual relations. This act of violence can be classified in the form of physical and psychological violence;

4. Economic violence: the form of economic neglect which is not routinely provided or in an adequate amount, restricting and/or the means to work properly inside or outside the home, so that the victim is under the perpetrators of the violence.

Violence against women is the 10th cause of death for women of childbearing age. (Komnas Perempuan \& US Embassy, 2009) It is estimated that around 2-3 million women are trafficked around the world per year and at least one in five women in their lives has experienced physical or sexual violence committed by men. (Revita \& Trioclarise, 2014; Revita \& Trioclarise, 2017, p. 1-4) Lack of knowledge makes the position of women as the victims worse. Most women think that what they experienced is not violence but part of her role asa wife. (Revita, 2018)

These women need to be stimulated and their awareness must be awakened and built up. Local wisdom as the socio-cultural order in the form of norms, knowledge, regulations, and skills of people in an area to meet common needs inherited from one generation to others. (Hidayati, 2016, p. 39) The local wisdom becomes a social foundation developed by the community to create the regularity and the balance between socio-cultural life of the community and the surrounding nature. Minangkabau, for example, has distinctive local wisdom that can create the harmonious life of the society. (Octavianus \& Revita, 2013)

\section{Results and Discussion}

Each ethnic and community has their local wisdom which mainly functions to bring about the balance in the circumstance of socio-cultural life. As the local wisdom is wisely implemented, the peaceful and quiet life can be achieved. No more crime nor violence, especially toward women. Minangkabau as the ethnic where is administratively located in West Sumatera has its own local wisdom that can put women in secured. There are at least three local wisdom owned by Minangkabau people to prevent the acts of violence toward women as explained below.

\subsection{Adat Basandi Syarak, Syarak Basandi Kitabullah}

Adat Basandi Syara', Syara' Basandi Kitabullah, Syara' Mangato Adat Mamakai is the philosophy of Minangkabau people which means that Minangkabau society must know Islam and understand the Minangkabau tradition. (Navies, 2017) This implies that Minangkabau people whose religion must be Islam will behave religiously and implement norms regulated in their tradition. That is in line with Adat Basandi Syara', Syara' Basandi Kitabullah 'Tradition is jointed with religion, religion must be hinged with Al-Quran'.

In Syara' Mangato Adat Mamakai, there are at least three elements that must be Minangkabau people put under their consideration. They are:

1. Religious understanding

Minangkabau people are Islam. None of the Minangkabau people is non-muslim. Islam in their faith guarantees the prosperity and welfare of life in the world and in the hereafter. So, every human being is obliged to seek for the knowledge of Islam. Faith or aqidah is a very important thing to be learned. The true aqidah will bring people to the truth but not to the deviations of religion and behavior. Aqidah is the foundation of the establishment of an integrated Islam in the six pillars of faith. Al-Qur'an and as-Sunnah are umbrellas or roofs that will maintain the pure aqidah and true worship.

2. Shari'ah

Shari'ah is all the rules and laws conceived in Islam sourced from the Qur'an and Sunnah. Running Shari'at correctly is the key to goodness. Adat 'tradition' also becomes the guide to virtue. Al-Qur'an and Sunnah are the sources of Syara '(Syari'at) that compasses Minangkabau customs.

3. Adat nan saban Adat understanding 'the real tradition/custom'

Customs that have been formulated by the clerics and public figures of Minang were formerly arranged in accordance with the guidance of Syara '(Syari'at) which originated from Qur'an and Sunnah. So, the real custom to be used by the Minang community is the custom of society which is not in contradictory with the Syara '(Syari'at). The Custom may be lost if religion has been ignored. It is like running water, a tributary will dry if the source is dead, if the creek is dry. So, customs have Syara '(Syari'at) as the foundation. If the Syara '(Syari'at) ' is not noticed any more or many people have left it, the custom would automatically 
disappear. This local wisdom has a close relationship with the treatment of women. Islam in Quran and Sunnah clearly state how to deal with women. No harshness nor violence needs to be executed through for the sake of education. Even, Islam regulates the way to express anger but not in a rough way.

\subsection{Bundo Kanduang}

Bundo Kanduang is defined as a) Bundo Kanduang dalam kaum; b) Limpapeh rumah nan gadang, amban paruik pagangan kunci, pusek jalo kumpulan tali, hiasan di dalam kampuang, sumarak dalam nagari, Nan gadang basa batuah;c) Ka pai tampek batanyo, kok pulang tampek babarito, kok hiduik tampek baniaik, kok mati tampaik banazar, ka undang-undang ka Madinah,payuang panji ka Sarugo, Muluik manih kucindam murah;d) Baso baiak gulo di bibie, muluik manih talempong kato, sakali rundiang disabuik, takana juo salamonyo, Masaklah buah kacang padi, padi nan masak batangkai-tangkai, dibawok urang katangah pasa, Bundo Kanduang tuladan budi, budinyo nan indak amuah tagadai, paham nan indak amuah tajua [2][18]. Bundo Kanduang is depicted as very ideal woman who is very noble.

Bundo Kanduang is derived from two words; that is bundo which means mother and kanduang that means true. Bundo Kanduang is a matured woman in which Minangkabau culture has placed her position in a very high position and noble, made her have a very strategic role and function in instilling customary values and Minangkabau culture, especially forming the morals of the young generation, and also expected to be able to solve other social problems, both in the family environment, relatives, and in the neighborhood, both as leaders in the community and as community leaders in villages or Nagari. (Revita, et al., 2017, pp. 97-98; (Oktavianus \& Revita, 2013)

Bundo Kanduang is also interpreted as a term or nickname towards women in Minangkabau who have maternal qualities as well as the qualities of leadership, who are intelligent, wise and noble-hearted.

Bundo Kanduang is a non-formal leader for all women and grandchildren in their people. Her leadership grew out of her own abilities and charisma recognized by members of the people concerned. The existence of Bundo Kanduang in a people is due to the need of a female leader who can lead all women and grandchildren in their people. Bundo Kanduang is not a formal position chosen in an official election. It is a leading figure who appears spontaneously among existing leaders. Her appearance indicated the ability and charisma that grew from inner supported by adequate knowledge accompanied by honesty and good behavior and accepted by all parties.

The local wisdom of Bundo Kanduang indirectly leads Minangkabau women to be wise to carry out all aspects of their life. They must be an honorable creature who does not need to violate or roughly treated. Bundo Kanduang as the female leader implies the competence and qualification of Minangkabau women.

Even, to glorify women, Minangkabau people call their wives as induak bareh (mother of rice). Philosophically, induak bareh means the mother of life. Bareh 'rice' is a source of energy for life. In Minangkabau, women are the mother of life reflected in the role of Bundo Kanduang. In the seed, there is a life that we cannot create. Seeing seeds like looking at the greatness and wonders of God.

\subsection{Alam Takambang Jadi Guru}

Alam takambang jadi guru has the philosophy of nature becomes a teacher, which means that the water that is speckled is accepted as much as ocean water, the land that is tight (hand-held) is willing to be accepted as big as a mountain, and this great universe is used as a teacher (a place of learning and/or teaching).

The knowledge learned from nature has given confidence to the ancestors of the Minangkabau people that all the secrets of the creation of the universe are stored in the properties of beings and things in the universe, where natural law applies. For example, is hot fire and burning, water soaking and nourishing, wood rooted, moaning and fruiting, sea choppy, misty mountain, crowing cock, goat roaring, or tiger roaring.

That natural law like fire burns or water soaks is a nature that is universally valid, logical, and indisputable. Based on such a view of life, the ancestors of the Minangkabau people have compiled and shaped the Minangkabau Customary Law, namely legal norms or unwritten legal rules that regulate the life of the Minangkabau people, from the smallest to the wider; political, economic, legal, or social.

Like every single part of Minangkabau people has been regulated in Minangkabau Customary Law, violence toward women is not supposed available. Minangkabau people may learn from nature as the women are insulted, hurt, or persecuted, they indirectly lead the culture into the destruction. Women are the agent of change. (Revita, 2017) Minangkabau women play a very significant role in their society. So, these Minangkabau do not deserve to be treated inhumanly like such violence. 


\section{Conclusions}

Violence toward women in Minangkabau is illogical and unreasonable because Minangkabau women are put in a certain and very noble position in society. Even, there are at least three local wisdom in Minangkabau that are impossible to find the fact about violence.

The three local pearls of wisdom are Adat Basandi Syarak, Syarak Basandi Kitabullah, 2) Bundo Kanduang), and 3) Alam takambang jadi guru. As these three local pearls of wisdom are wisely implemented, there will be no violence toward women in Minangkabau. However, the fact says otherwise. This is due to a lack of understanding of this set of local wisdom. Therefore, it is necessary to revive the Minangkabau local wisdom as well as the empowerment for women. So, these women are aware of their self-esteem and dignity. Furthermore, they can also be protected from violence. Even, Minangkabau is free from the violence toward women.

\section{References}

1. Asmarany, L. M. (2007) “Bias Gender Sebagai Prediktor Kekerasan Dalam Rumah Tangga," Gend. Bias Sebagai Prediktor Kekerasan Dalam Rumah Tangga, vol. 35, no. 1, pp. 1-20.

2. DEVAW, (1993) "DEVAW (Declaration on the Elimination of Violence Against Women). Deklarasi tentang Penghapusan Kekerasan terhadap Perempuan tahun 1993."

3. Erikkson, M., Bruno, L \& Nasma, E. (2013) Domestic Violence, Family Law and School. London: Macmillan Publishers Limited.

4. Hastuti, E., Julianti, D., Erlangga, D \& Oswari, T. (2013) "Kearifan Lokal Sosial Budaya Masyarakat Minang Pedagang Rantau di Jakarta," PESAT (Psikologi, Ekon. Sastra, Arsit. Sipil), vol. 5, pp. 8-9

5. Hayati, E.N (2002) Panduan utuk Pendamping Perempuan Korban Kekerasan: Konseling Berwawasan Gender, cet. Ke-2, vol. 2. Yogyakarta: Rifka Annisa Kerja Sama dengan Pustaka Pelajar.

6. Hidayati, D. (2016) "Memudarnya Nilai Kearifan Lokal Masyarakat Dalam Pengelolaan Sumber Daya Air," J. Kependud. Indones., vol. 11, no. 1, p. 39

7. Idriss, M.M and Abbs, T. (2001) Honour, Violence, Women and Islam. United Kingdom: Routledge.

8. Komnas Perempuan dan US Embassy. (2009). Perlindungan Saksi dan Korban. Jakarta: Komnas Perempuan,"

9. Martha, A. E. (2003) Perempuan Kekerasan dan Hukum. Jogjakarta: UII Press Jogjakarta.

10. Navies, A. (2017) Pemikiran Minangkabau Catatan Budaya A.A Navies. Bandung: Angkasa.

11. Oktavianus and Revita, I. (2013) Kesantunan Berbahasa, 1st ed. Padang: MInangkabau Press.

12. Oram, S., Khalifeh, H \& Howard, L. M. (2017) "Violence Against Women and Mental Health" The Lancet Psychiatry, vol. 4, no. 2, pp. 159-170.

13. Revita, I “Revita.pdf.” Harian Singgalang, Padang, 2016.

14. Revita, I and Trioclarise, R. (2014) "Efek Perlokusi-Medis Korban Women Trafficking," in Semiotik dan Pragmatik, 2014.

15. Revita, I and Trioclarise, R. (2017) "Medical-Pragmatics Analysis of Activities Of Women Trafficking In West Java : Portrait Of The Victims," in The 3rd International Seminar on Linguistics (ISOL-3), no. 3, pp. 1-4.

16. Revita, I. (2017) Women Trafficking dalam Bingkai Sosiopragmatik.pdf, I, Juli 2017. Padang: Visigraf.

17. Revita, I. (2018) Kaleidoskop Linguistik.pdf, I, 2018. Padang: CV. Rumahkayu Pustaka Utama.

18. Revita, I., Trioclarise, R \& Gunawan, F. (2017) "Matrilinial System and the Activity of Women Trafficking in West Sumatera," in Proceedings of the 2nd International Conference on Education, Science, and Technology (ICEST 2017), pp. 97-99.

19. Revita, I., Wekke, I. S \& Trioclarise, R. (2018) "Empowering the Values of Minangkabau Local Wisdom in Preventing the Activity of Women Trafficking in West Sumatera," IOP Conference Series : Earth and Environmental Sciences pp. 3-6.

20. United Nation, Article 1 of the UN Declaration.

21. UU, "UU Nomor 23 Tahun 2004 tentang Penghapusan kekekrasan dalam Rumah Tangga." Jakarta, 2004. 